\title{
PERLINDUNGAN HUKUM YANG ADIL ATAS HILANGNYA BAGASI PENUMPANG DALAM PENGANGKUTAN UDARA
}

\author{
Rosalita Ardiani Putri, Bambang Eko Turisno.2 \\ Program Studi Magister Ilmu Hukum \\ Fakultas Hukum Universitas Diponegoro
}

\begin{abstract}
ABSTRAK
Keselamatan pada kegiatan pengangkutan udara menyangkut jiwa seorangpenumpang dan terhadap bagasi atau barang yang mereka bawa.Permasalahan yang dibahas dalam tesis ini adalah bagaimana perlindungan hukum yang adil atas hilangnya bagasi penumpang dalam pengangkutan udara dan bagaimanakah putusan pengadilan tentang sengketa hilangnya bagasi penumpang menurut teori keadilan. Metode penelitian yang digunakan dalam tesis ini adalah penelitian yuridis empiris. Spesifikasi penelitian yang digunakan adalah deskriptis analitis. Metode pengumpulan data dilakukan menggunakan data primer melalui wawancara dan data sekunder melalui studi kepustakaan. Hasil penelitian menyimpulkan bahwa perlindungan hukum atas hilangnya bagasi pada pengangkutan udara dirasa belum cukup adil bagi para penumpang, terutama terlihat pada isi perjanjian pengangkutan dan besar ganti kerugian. Putusan hakim pengadilan mengenai tanggung jawab pengangkut udara yang dibahas dalam tesis ini telah sesuai dengan teori keadilan milik John Rawls "J ustice as Fairness", yaitu keadilan yang paling fair atau yang paling jujur yang harus dijadikan sebagai pedoman.
\end{abstract}

\section{Kata Kunci : Adil; Bagasi Angkutan Udara; Perlindungan Hukum}

1Mahasiswa Program Studi Magister IImu Hukum UNDIP

${ }^{2}$ Penulis Kedua, Penulis Koresponden 


\section{PENDAHULUAN}

\section{A. Latar Belakang}

Globalisasi telah melahirkan konsep dunia tanpa batas yang membuat dunia seakan-akan menjadi sangat kecil.Salah satu manfaat globalisasi di bidang ekonomi adalah perkembangan teknologi dan transportasi yang pesat di seluruh penjuru dunia. Kemajuan teknologi dan transportasidi Indonesia dapat secara langsung kita rasakan pada transportasi udara. Hal ini ditunjukkan dengan meningkatnya pengguna jasa penerbangan di berbagai rute baik domestik maupun internasional dengan jadwal terbang yang padat setiap harinya. Badan Pusat Statistik (BPS) Indonesia mencatat jumlah penumpang yang berangkat dari Bandara Soekarno Hatta pada bulan Agustus 2014 adalah sebanyak 1.749 .164 orang. Angka tersebut mengalami peningkatan yang cukup besar apabila dibandingkan dengan jumlah penumpang pada bulan Agustus tahun 2006 yang hanya mencapai 938.124 jiwa. ${ }^{3}$ Meningkatnyaminat masyarakat pada angkutan udara diikuti pula dengan peningkatan jumlah perusahaan penerbangan yang beroperasi di wilayah Indonesia.cukup menghawatirkan apabila perusahaan penerbangan tidak mengimbanginya dengan peningkatan kualitas pelayanan sehingga rawan terhadap keselamatan

\footnotetext{
${ }^{3}$ Badan Pusat Statistik Indonesia, http://www.bps.go.id/tab_sub/view.php?tabel=1\&dafta $\underline{r}=1 \& i d \_s u b j e k=17 \&$ notab $=8$ diunduh pada tanggal 19 November 2014 pukul 20.50 WIB.
}

dan akan berdampak kurang baik terhadap keamanan, kenyamanan, dan perlindungan konsumen. ${ }^{4}$

Bagasi merupakan salah satu objek pengangkutan udara selain penumpang dan kargo, ${ }^{5}$ sehingga sudah menjadi kewajiban pengangkut untuk melaksanakan pengangkutan bagasi penumpang dengan selamat sampai di tempat tujuan. Istilah "selamat" mengandung arti bila pengangkutan berjalan dengan "tidak selamat" itu menjadi tanggung jawab pengangkut. Keadaan "tidak selamat" ini mempunyai dua makna yaitu barangnya tidak ada, lenyap, musnah atau barangnya ada tetapi rusak sebagian atau seluruhnya 6 Perlindungan hukum pada pengangkutan udara tidak hanya terdapat dalam Hukum Penerbangan, tetapi juga Hukum Perlindungan Konsumen. Penumpang sebagai pemilik bagasi perlu mendapatkan perlindungan hukum ataskelalaian yang dilakukan oleh pihak pengangkut. Besar ganti rugi/kompensasi yang diberikan pengangkut pada beberapa kasus dinilai para penumpang (korban) belum memuaskan, sehingga mereka memilih untuk menyerahkan

\footnotetext{
${ }^{4}$ E. Saefullah Wiradipraja, 2006, Tanggung Jawab Perusahaan Penerbangan terhadap Penumpang menurut Hukum Udara Indonesia, Jakarta: Jurnal Hukum Bisnis Vol. 25, hlm. 5.

${ }^{5}$ Ibid., hlm. 33.

${ }^{6}$ H.M.N. Purwosutjipto, 1983, Pengertian Pokok Hukum Dagang Indonesia: Hukum Pertanggungan, Jakarta: Djambatan, hlm. 2.
} 
penyelesaian sengketa tersebut kepada pihak pengadilan.

Dengan melihat kenyataan yang diuraikan, permasalahan yang dapat dirumuskan adalah sebagai berikut:

1. Bagaimana perlindungan hukum yang adil atas hilangnya bagasi penumpang dalam pengangkutan udara?

2. Bagaimanakah putusan pengadilan tentang sengketa hilangnya bagasi penumpang angkutan udara menurut teori keadilan?

\section{B. Metode Penelitian}

Metode Penelitian yang digunakan dalam tesis ini adalah penelitian yuridis empiris. Spesifikasi penelitian yang digunakan adalah deskriptif analitis. Metode pengumpulan data dilakukan menggunakan data primer melalui wawancara terarah dan data sekunder melalui studi pustaka. Metode analisis data menggunakan metode kualitatif.

\section{Kerangka Konsep}

1. Perlindungan Hukum pada Konsumen

Perlindungan hukum adalah perlindungan akan harkat dan martabat, serta pengakuan terhadap hak-hak asasi manusia yang dimiliki oleh subjek hukum berdasarkan ketentuan hukum dari kesewenangan. ${ }^{7}$ Berkaitan dengan konsumen, berarti hukum memberikan perlidungan terhadap hak-hak pelanggan dari sesuatu yang

${ }^{7}$ Philipus M. Hadjon, 1987, Perlindungan Hukum bagi Rakyat Indonesia, Surabaya: Bina Ilmu, hlm. 108. mengakibatkan tidak terpenuhinya hak-hak tersebut.

Undang-undang Perlindungan Konsumen Nomor 8 Tahun 1999 dalam Pasal 1 angka 1 mengartikan perlindungan konsumen sebagai segala upaya yang menjamin adanya kepastian hukum untuk memberi perlindungan kepada konsumen.Berdasarkan pengertian perlindungan konsumen tersebut, Az. Nasution menjelaskan, hukum perlindungan konsumen adalah keseluruhan asas-asas dari kaidahkaidah yang mengatur dan melindungi konsumen dalam hubungan dan masalah penyediaan dan penggunaan produk konsumen antara penyedia dan penggunanya, dalam kehidupan bermasyarakat. ${ }^{8}$

2. Teori Keadilan

Istilah "keadilan" berasal dari kata dasar adil atau adl dalam bahasa Arab. Makna adil dalam Kamus Besar Bahasa Indonesia adalah sikap yang berpihak kepada yang benar, tidak memihak salah satuya, tidak berat sebelah, sedangkan keadilan adalah sikap dan sifat serta perlakuan yang tak berat sebelah. ${ }^{9}$ Berikut adalah beberapa definisi keadilan menurut para ahli : 10

\footnotetext{
${ }^{8}$ Az. Nasution, 1995, Konsumen dan Hukum, Jakarta: Muliasari, hlm. 22-23.

${ }^{9}$ Sulchan Yasyin, 2011, Kamus Besar Bahasa Indonesia, Jakarta: Gramedia, hlm. 12.

${ }^{10}$ Achmad Ali, 2009, Menguak Teori Hukum (Legal Theory) dan Teori Peradilan (Judicialprudence) :
} 
a. J ustice has always weighted the scale solely in favour of the weak and persecuted. A justice desicion is a decision based on grounds which appeal to a disinterested person. (Eugen Ehrlich)

b. J ustice requires that freedom, equality, and security be accorded to human beings to the greatest extent consisten eith the common good. (Bodenheimer)

Aristoteles menyatakan bahwa ukuran dari keadilan adalah : ${ }^{11}$ Seseorang tidak melanggar hukum yang berlaku sehingga keadilan berarti "lawful" yaitu hukum tidak boleh dilanggar dan aturan hukum harus diikuti, serta seseorang tidak boleh mengambil lebih dari haknya, sehingga keadilan berarti persamaan hak (equal).

Berbeda dengan Aristoteles, John Rawls mengembangkan teori keadilan sebagai J ustice as Fairness (keadilan sebagai kejujuran). Jadi, prinsip keadilan yang paling fair atau jujur itulah yang harus dipedomani. Menurut Rawls cara yang adil untuk mempersatukan berbagai kepentingan yang berbeda, adalah melalui keseimbangan kepentingan-kepentingan tersebut tanpa memberikan perhatian istimewa terhadap kepentingan itu sendiri. ${ }^{12}$

3. Bagasi Penumpang dalam Pengangkutan Udara

termasuk Interpretasi Undang-undang

(Legisprudence), Jakarta: Kencana, hlm. 217

${ }^{11}$ Aristoteles, dalam Munir Fuady, 2007, Dinamika

Teori Hukum, Bogor: Ghalia Indonesia, hlm. 92.

${ }^{12}$ Ahmad Ali, Op.Cit., hlm. 279.
Pasal 1 angka 13 Undang-undang No.1 Tahun 2009 tentang Penerbangan memberikan definisi mengenai pengangkutan udara yaitu setiap kegiatan dengan menggunakan pesawat udara untuk mengangkut penumpang, kargo, dan/atau pos untuk satu perjalanan atau lebih dari satu bandar udara ke bandar udara yang lain atau beberapa bandar udara.

Definisi bagasi dalam Pasal 6 ayat (2) Ordonansi Pengangkutan Udara Stb.1939-100 adalah semua barang kepunyaan atau di bawah kekuasaan penumpang yang olehnya atau atas namanya sebelum ia menumpang pesawat terbang, diminta untuk diangkut melalui udara.Undang-undang Penerbangan No. 1 Tahun 2009 membedakan bagasi angkutan udara (penerbangan) menjadi 2 (dua) macam, yaitu bagasi tercatat dan bagasi kabin.

a) Bagasi Tercatat adalah barang penumpang yang diserahkan oleh penumpang kepada pengangkut untuk diangkut dengan pesawat udara yang sama.

b) Bagasi Kabin adalah barang yang dibawa oleh penumpang dan berada dalam pengawasan penumpang sendiri.

\section{HASIL PENELITIAN DAN PEMBAHASAN}

\section{A. Perlindungan Hukum yang Adil atas Hilangnya Bagasi Penumpang Angkutan Udara}


1. Perlindungan menurut Perjanjian Pengangkutan Udara

Dalam suatu tiket biasanya tercantum ketentuan bahwa pengangkutan udara tunduk pada "syarat-syarat umum pengangkutan" yang berlaku di perusahaan penerbangan yang bersangkutan. Syaratsyarat perjanjian pengangkutan sebenarnya adalah ditetapkan secara sepihak oleh perusahaan penerbangan, karena merupakan perjanjian baku (standar). Perjanjian baku pada prinsipnya hanya menguntungkan pelaku usaha dan merugikan konsumen karena klasulanya yang tidak seimbang dan tidak mencerminkan keadilan sehingga dominasi pengangkut lebih besar dibandingkan dengan penumpang. Akibat kedudukan para pihak yang tidak seimbang, maka penumpang tidak berada dalam keadaan yang betul-betul bebas untuk menentukan apa yang dinginkannya dalam perjanjian. Hal ini bertentangan dengan asas kebebasan berkontrak dan asas konsesualisme yang diatur dalam Pasal 1320 dan Pasal 1338 KUHPerdata.

2. Hak Penumpang atas Kenyamanan, Keamanan, dan Keselamatan

Seorang konsumen memiliki hak atas kenyamanan, keamanan, dan keselamatan dalam menggunakan barang dan/atau jasa yang ditawarkan oleh pelaku usaha, sebagaimana bunyi Pasal 4 ayat (1) Undangundang Perlindungan Konsumen. Ketiga unsur tersebut dimaksudkan untuk menjamin keamanan dan keselamatan konsumen agar dapat terhindar dari kerugian (fisik maupun psikis) atas pemakaian barang dan/atau jasa yang membahayakan keselamatan. Kenyamanan, keamanan, dan keselamatan juga merupakan faktor penting yang harus dipenuhi pengangkut dalam melakukan kegiatan pengangkutan udara, bukan hanya terhadap jiwa seseorang (penumpang) tetapi juga terhadap barang-barang yang penumpang bawa untuk diangkut.

3. Hak Penumpang atas Pelayanan yang Layak dari Pengangkut

Setiap penumpang berhak atas pelayanan yang layak dari pengangkut atau pemilik jasa angkutan udara. Berdasarkan Pasal 140 Undang-undang Penerbangan No. 1 Tahun 2009, pelayanan yang layak harus sesuai dengan perjanjian pengangkutan yang telah disepakati. Pelayanan ini dimulai sejak penumpang melakukan check in pada bandara keberangkatan hingga turun dari pesawat sesampainya di bandara tujuan. Pelayanan yang layak termasuk juga pada layanan saat terjadi klaim atas bagasi milik 
penumpang yang hilang sampai dengan pemberian ganti kerugian kepada penumpang.

4. Hak Penumpang atas Informasi yang Benar, Jelas, dan Jujur mengenai Kondisi Barang dan/atau Jasa yang Ditawarkan Pelaku Usaha

Berdasarkan Pasal 4 ayat (3) Undangundang Perlindungan Konsumen, maka seorang pengangkut harus berkewajiban untuk memberikan informasi yang benar, jelas, dan jujur mengenai ketentuanketentuan yang terdapat dalam perjanjian pengangkutan. Setiap keterangan mengenai suatu barang atau jasa yang akan dibelinya haruslah diberikan selengkap mungkin dan penuh dengan kejujuran. Informasi baik secara langsung maupun secara umum seharusnya disepakati bersama agar tidak menyesatkan konsumen. Namun pada praktik pengangkutan udara,pengangkut tidak memberikan informasi yang jelas mengenai hak penumpang dan besar ganti kerugian yang akan diperoleh apabila bagasi miliknya hilang.

5. Hak Penumpang untuk Memperoleh Tanda Pengenal Bagasi

Setiap penumpang yang menyerahkan Bagasi tercatat miliknya kepada pengangkut, harus diberi tanda pengenal bagasi yang paling sedikit memuatnomor tanda pengenal bagasi;kode tempat keberangkatan dan tempat tujuan; danberat bagasi. ${ }^{13}$

Ketentuan tersebut kurang memadai dan bahkan jauh lebih ringkas daripada ketentuan Pasal 4 Konvensi Warsawa 1929 mengenai hal-hal yang perlu dicantumkan dalam label bagasi penumpang. Tanda pengenal bagasi bahkan tidak termuat nama dan alamat pemilik. Pengangkut juga tidak berkewajiban untuk memberitahu penumpang mengenai jumlah pertanggungan bagasi. Hal ini tentu sangat merugikan dan belum melindungi penumpang secara maksimal.

6. Hak Penumpang untuk Membuat Perjanjian Pengangkutan Khusus dengan Pengangkut Bentuk perlindungan lain yang terdapat dalam Pasal 169 Undang-undang Penerbangan adalah aturan di mana kedua belah pihak (pengangkut dan penumpang) dapat membuat persetujuan khusus untuk menentukan ganti kerugian yang lebih tinggi daripada yang terdapat dalam undangundang. Namun, bagaimana mungkin seorang penumpang dapat membuat persetujuan untuk menetapkan jumlah ganti kerugian yang lebih tinggi sementara penumpang yang bersangkutan tidak

\footnotetext{
${ }^{13}$ Pasal 153 Undang-undang Penerbangan No.1 Tahun 2009
} 
diberitahu mengenai besar ganti rugi yang masih berlaku? Niat untuk melindungi kepentingan penumpang tersebut pada kenyataannya akan sulit diwujudkan meskipun diperbolehkan oleh Undangundang Penerbangan.

7. Hak Penumpang untuk Memperoleh Tanggung Jawab/ Ganti Kerugian

Berdasarkan Pasal 143 dan Pasal 144 Undang-undang Penerbangan, pengangkut wajib bertanggung jawab atas kerugian yang diderita oleh penumpang karena bagasi tercatat hilang, yang diakibatkan oleh kegiatan angkutan udara selama bagasi tercatat berada dalam pengawasan pengangkut. Pengangkut juga harus bertanggung jawab atas hilangnya bagasi kabin milik penumpang apabila kerugian tersebut disebabkan oleh tindakan pengangkut atau orang yang dipekerjakannya. Bentuk tanggung jawab yang harus dilakukan oleh pengangkut menurut Undang-undang Penerbangan adalah dengan pemberian ganti rugi sejumlah uang tertentu kepada para korban (penumpang).

Ganti kerugian atas hilangnya bagasi milik penumpang dalam UU Penerbangan diatur lebih lanjut pada Peraturan Menteri Perhubungan No. 77 Tahun 2011 tentang
Tanggung Jawab Pengangkut Angkutan Udara.

Berdasarkan Pasal 5 Permenhub tersebut, ganti rugi terhadap penumpang yang kehilangan bagasi tercatat atau isi bagasi tercatat atau bagasi tercatat musnah adalah sebesar Rp. 200.000,00 per kg dan paling banyak Rp. 4.000.000,00 per penumpang. Kerugian yang muncul atas hilang atau rusaknya bagasi kabin tidak akan ditanggung oleh pengangkut kecuali apabila penumpang dapat membuktikan bahwa kerugian tersebut disebabkan oleh tindakan pengangkut atau orang yang dipekerjakannya.Menurut pandangan John Rawls, keadilan merupakan Justice as Fairness (keadilan sebagai kejujuran). ${ }^{14}$ Prinsip keadilan yang paling fair atau yang paling jujur itulah yang harus dipedomani atau dengan kata lain keadilan dinilai dari kejujuran hati yang paling dalam. Apakah dapat dikatakan adil jika perhitungan ganti rugi hanya didasarkan pada berat bagasi, bukan kerugian nyata penumpang? Seseorang yang kehilangan bagasi seberat 5 kilogram dengan total kerugian sebesar Rp 8.000.000,- (delapan juta rupiah) akan diganti dengan uang senilai $\mathrm{Rp} 1.000 .000$,(satu juta rupiah), sementara penumpang lain yang membawa bagasi $20 \mathrm{~kg}$ dengan

\footnotetext{
${ }^{14}$ Susanti Adi Nugroho, Op.Cit., hal 54.
} 
kerugian Rp 2.000.000,- (dua juta rupiah) justru diberikan ganti rugi senilai $\mathrm{Rp}$ 4.000.000,- (empat juta rupiah).

Dari berbagai bentuk perlindungan hukum di atas, baik yang tercantum pada perjanjian pengangkutan, Undang-undang Penerbangan, maupun Undang-undang Perlindungan Konsumen, pada kenyataannya belum cukup adil untuk melindungi kepentingan penumpang atas hilangnya bagasi dalam pengangkutan udara. Hal ini terjadi karena adanya ketidakseimbangan posisi antara pengangkut dengan penumpang. Pengangkut lebih dominan dalam menentukan isi dan syaratsyarat perjanjian pengangkutan udara, sementara penumpang hanya diam dan tidak diberi kesempatan untuk merubah. Hak-hak penumpang sebagaimana diatur pada peraturan perundang-undangan juga sering diabaikan dan tidak dipenuhi oleh pengangkut, misalnya hak atas informasi yang jelas. Selain itu, ganti kerugian yang tercantum pada Peraturan Menteri Perhubungan No.77 Tahun 2011 juga tidak adil bagi para penumpang karena ditentukan terbatas pada berat bagasi, bukan pada kerugian nyata yang dialami oleh penumpang.

\section{B. Putusan Pengadilan tentang Sengketa Hilangnya Bagasi Penumpang Angkutan Udara Menurut Teori Keadilan}

Putusan pengadilan yang penulis gunakan pada penelitian hukum ini adalah putusan PN Jakarta Pusat No. 172/PDT.G/2009/PN.JKT.PST; putusan MA No. 605 K/Pdt.Sus-BPSK/2012 jo putusan PN Semarang No. 02/Arbitrase/2011/PN.Smg. jo putusan BPSK Kota Semarang No.12 BPSK-SMG/Put Arbitrase/X/2011; serta putusan MA No. 820 K/PDT/2013 jo. putusan PT Semarang No. 254/PDT/2012/PT.Smg. jo. putusan PN Semarang No. 304/Pdt.G/2011/PN.SMG. Ketiga putusan tersebut menghukum pengangkut untuk membayar ganti kerugian kepada penumpang dengan nominal yang jauh lebih besar daripada aturan Undang-undang Penerbangan, yaitu Rp 5.140 .000 pada putusan pertama, Rp 25.000.000,- pada putusan kedua, dan Rp 38.230.000,- pada putusan terakhir.Penulis berpendapat bahwa ketiga putusan pengadilan di atas telah sesuai dengan teori keadilan milik John Rawls "Justice as Fairness" (keadilan sebagai kejujuran/ kelayakan). ${ }^{15}$ Prinsip keadilan yang paling fair atau yang paling jujur itulah yang harus dipedomani. Pada putusan tersebut, hakim lebih mengutamakan unsur kelayakan dan kepantasan dalam menentukan jumlah ganti rugi yang harus dibayar oleh pengangkut. Kelayakan dan

\footnotetext{
${ }^{15} I b i d .$, hal 54.
} 
kepantasan tersebut dinilai berdasarkan kerugian nyata terhadap isi bagasi yang hilang, bukan berdasarkan berat bagasi. Sikap hakim yang mengesampingkan ketentuan ganti rugi menurut Peraturan Menteri No. 77 Tahun 2011 tentang Tanggung Jawab Pengangkut Udara, menunjukan bahwa hakim lebih mengedepankan keadilan substantif daripada keadilan formal. Undangundang Kekuasaan Kehakiman No. 4 Tahun 2004 juga menyebutkan jika hakim wajib menggali, mengikuti, dan memahami nilai-nilai hukum, dan rasa keadilan yang hidup di dalam masyarakat. ${ }^{16}$ Berdasarkan bunyi Pasal tersebut, maka sudah seharusnya hakim tidak hanya terpaku pada ketentuan undang-undang atau peraturan tertulis lainnya, melainkan juga mempertimbangkan rasa keadilan dalam masyarakat.

Gustav Radbruch menyebutkan tiga nilai dasar yang harus diwujudkan dan perlu mendapat perhatian serius dari para pelaksana hukum, yaitu nilai keadilan, kepastian hukum, dan kemanfaatan. 17 Sekalipun ketiga-tiganya merupakan nilai dasar dari hukum, namun di antara mereka terdapat suatu ketegangan satu sama lain. Keadaan yang demikian bisa dimengerti karena ketiganya berisi tuntutan yang berlainan dan mengandung potensi untuk bertentangan satu

\footnotetext{
${ }^{16}$ Pasal 28 UU Kekuasaan Kehakiman No.4 Tahun 2004.

${ }^{17}$ Gustav Radbruch dalam Satjipto Rahardjo, 2006, Ilmu Hukum Cetakan Keenam, Bandung: Citra Aditya Bakti, hlm. 19.
}

sama lain. Begitu pula yang terjadi pada penyelesaian sengketa bagasi penumpang di atas. Hakim lebih mengutamakan pada terwujudnya keadilan dan kemanfaatan sehingga ia harus menggeser nilai kepastian hukum ke samping. Sikap hakim yang mengesampingkan nilai kepastian hukum tersebut penulis rasa sudah tepat. Hakim tidak mengikuti ketentuan Pasal 5 Peraturan Menteri Perhubungan No.77 Tahun 2011 mengenai ganti kerugian pengangkut atas hilangnya bagasi penumpang karena aturan tersebut tidak dapat mewujudkan keadilan bagi kedua belah pihak. Kerugian nyata yang dialami oleh penumpang jauh lebih besar dan tidak sebanding dengan nilai ganti rugi yang telah ditentukan. Permenhub tersebut juga sudah tidak sesuai untuk digunakan sebagai dasar penentuan ganti rugi karena belum pernah dievaluasi sejak tahun penerbitan yaitu tahun 2011. Hal ini bertentangan dengan bunyi Pasal 162 Undang-undang Penerbangan yang mengamanatkan untuk dilakukan evaluasi terhadap peraturan menteri terkait paling sedikit 1 (satu) kali setiap tahun dengan mempertimbangkan tingkat hidup yang layak; kelangsungan hidup Badan Usaha Angkutan Udara; tingkat inflasi kumulatif; dan perkembangan nilai mata uang. Ganti kerugian dalam Permenhub juga jauh lebih rendah dengan aturan internasional sebagaimana termuat pada Pasal 22 Konvensi Montreal 1999 yaitu 1.131 SDR atau sebesar Rp 20.437.170,- (dua puluh juta 
empat ratus tiga puluh tujuh ribu seratus tujuh puluh rupiah).

Pemerintah seharusnya memperbaiki atau merevisi aturan ganti rugi dalam Permenhub No.77 Tahun 2011 seiring dengan perkembangan perekonomian Indonesia. Perbaikan ini dinilai sangat penting karena jumlah ganti rugi atas hilangnya bagasi penumpang dalam pengangkutan udara sangat bergantung pada bunyi undangundang atau peraturan tertulis lainnya. Jika nilai ganti rugi tidak segera disesuaikan dengan perkembangan sosial dan ekonomi masyarakat, maka para penumpanglah yang akan dirugikan.

\section{PENUTUP}

\section{A. Simpulan}

1. Perlindungan hukum atas hilangnya bagasi pada pengangkutan udara dirasa belum cukup adil bagi para penumpang, terutama pada isi perjanjian pengangkutan dan besar ganti kerugian. Perjanjian pengangkutan udara dibuat secara baku oleh pengangkut sendiri tanpa melibatkan penumpang, sehingga menyebabkan posisi yang tidak seimbang antara pengangkut dengan penumpang. $\mathrm{Hal}$ itu bertentangan dengan teori keadilan menurut Aristoteles yang menyatakan bahwa keadilan berarti persamaan hak (equal), karena hak pengangkut jauh lebih besar daripada hak penumpang.
Besar ganti kerugian atas hilangnya bagasi penumpang sebagaimana diatur dalam Pasal 5 Peraturan Menteri Perhubungan No. 77 Tahun 2011 tentang Tanggung Jawab Pengangkut Angkutan Udara adalah Rp 200.000,- (dua ratus ribu rupiah) per kilogram atau paling banyak adalah Rp 4.000.000,- (empat juta rupiah) per penumpang. Nominal tersebut juga tidak adil bagi para penumpang karena ditentukan dan terbatas pada berat bagasi, bukan pada kerugian nyata yang dialami. Peraturan Menteri Perhubungan No. 77 Tahun 2011 ini belum pernah di evaluasi sejak tahun pembentukannya.

2. Putusan pengadilan yang penulis gunakan pada penelitian hukum ini menghukum pengangkut untuk membayar ganti kerugian kepada penumpang dengan nominal yang jauh lebih besar daripada aturan Undang-undang Penerbangan, yaitu Rp 5.140.000 pada putusan pertama, Rp 25.000.000,- pada putusan kedua, dan Rp 38.230.000,- pada putusan terakhir. Putusan hakim tersebut telah sesuai dengan teori keadilan milik John Rawls "Justice as Fairness" di mana keadilan yang paling fair atau yang paling jujur yang harus dijadikan sebagai pedoman. Hakim lebih mengutamakan unsur kelayakan dan kepantasan dalam menentukan besar ganti rugi yang harus dibayar oleh pengangkut, yaitu berdasarkan kerugian nyata 
yang dialami penumpang, bukan pada berat bagasi.

\section{B. Saran}

1. Maskapai penerbangan sebagai pengangkut seharusnya beritikad baik dalam menyelenggarakan kegiatan angkutan udara. Itikad baik tersebut diwujudkan dengan cara memenuhi hak para penumpang, termasuk hak atas keamanan, keselamatan, dan hak atas informasi yang jelas tentang isi perjanjian pengangkutan.

2. Pemerintah Indonesia sebaiknya segera melakukan ratifikasi terhadap Konvensi Montreal 1999 agar dapat melindungi kepentingan para penumpang angkutan udara, bukan hanya dalam lingkup nasional tetapi juga secara internasional. Menteri Perhubungan sebaiknya juga melakukan pembaharuan terhadap Peraturan Menteri Perhubungan No. 77 Tahun 2011 tentang tanggung jawab pengangkut angkutan udara, terutama pada bagian ganti rugi atas hilangnya bagasi milik penumpang. Hal ini perlu dilakukan karena ganti kerugian pada aturan tersebut sudah tidak dapat memenuhi rasa keadilan bagi para korban (pemilik bagasi).

\section{DAFTAR PUSTAKA}

Ali, Achmad. 2009.Menguak Teori Hukum (Legal Theory) dan Teori Peradilan (J udicialprudence): termasuk Interpretasi Undang-undang (Legisprudence). Jakarta: Kencana.

Fuady, Munir. 2007. Dinamika Teori Hukum. Bogor: Ghalia Indonesia.

Hadjon, Philipus M. 1987.Perlindungan Hukum bagi Rakyat Indonesia. Surabaya: Bina IImu.

- 1994. Pengkajian IImu Hukum Dogmatik. Surabaya: Fakultas Hukum Universitas Airlangga.

Nasution, Az. 1995. Konsumen dan Hukum. Jakarta: Muliasari.

Purwosutjipto, H.M.N. 1981.Pengertian Pokok Hukum Dagang Indonesia III : Hukum Pengangkutan. Jakarta: Djambatan. 1983. Pengertian Pokok Hukum Dagang Indonesia: Hukum Pertanggungan. Jakarta: Djambatan.

Rahardjo, Satjipto. 2006. IImu Hukum Cetakan Keenam. Bandung: Citra Aditya Bakti. 
Jurnal Law Reform

Volume 11, Nomor 1, Tahun 2015

Wiradipraja, E. Saefullah. 2006.Tanggung J awab Perusahaan Penerbangan terhadap Penumpang menurut Hukum Udara Indonesia. Jakarta: Jurnal Hukum Bisnis Vol. 25.
Program Studi Magister IImu Hukum Fakultas Hukum Universitas Diponegoro 